\title{
熱応力緩和型傾斜機能材料の $\mathrm{H}_{2} / \mathrm{O}_{2}$ 燃焼ガス加熱による \\ 遮熱，耐熱特性評価
}

\author{
川崎 亮* 日比野 敦* 渡辺龍三*
}

J. Japan Inst. Metals, Vol. 56, No. 4 (1992), pp. 472-480

Thermomechanical Behavior of Thermal-Stress Relief Type of Functionally

Gradient Material Evaluated by Differential Temperature

Heating Using $\mathrm{H}_{2} / \mathrm{O}_{2}$ Combustion Flame

\begin{abstract}
Akira Kawasaki*, Atsushi Hibino* and Ryuzo Watanabe*
The burner heating test for thermomechanical evaluation of functionally gradient material in a laboratory scale has been described. A temperature difference was given by heating the ceramic side with a burner frame and cooling the metal side with water flow. The damage at the specimen surface was monitored with a microscope. A vertical crack formation at the ceramic surface was observed during cooling cycle. The test temperature for the first crack formation was defined as a thermal barrier performance value for the test sample. It has been found that the crack formation temperature is almost constant for the various samples and heating conditions, which indicates strong dependency of the thermal barrier property on the material species. The crack formation mechanism was discussed on the basis of a thermal stress analysis using a finite element method.
\end{abstract}

(Received January 7, 1992)

Keywords: functionally gradient material, hot pressing, burner heating test, thermomechanical evaluation, thermal barrier performance, temperature difference, thermal stress, fracture mechanism

\section{I . は じめに}

次世代の宇宙往還機の機体表面や推進システムに対して 従来の材料技術を適用することは，耐熱性能の点で限界に 達して括り，あらたな耐熱材料の開発が切望されている. 熱応力緩和型傾斜機能材料(FGM) は，このような背景の 中で提案された新しい概念の超耐熱材料であり，セラミッ クスと金属材料が持つ優れた特性を同時に発現させるもの である(1)(2).すなわち，表面にセラミックスを配して遮熱 性と耐熱性を，裏面に金属を配して強度と勒性扣よび他部 材との接合機能を与え，その間の組成分布を連続的に変化 させることにより，物性值の不連続性をなくして熱応力緩 和を図っている(3)(4). 組成分布は, これらの諸機能に対し て要求された条件を満たすよらに最適化されたものであ る(5).

傾斜機能材料の表面側は機体表面や燃燒器内壁などのよ らな高温環境にさらされ，裏面側は強制冷却される苛酷な 環境下で使用される。したがって，急速な加熱に対する熱 衝撃, 過渡的熱負荷を含む定常加熱, およびその繰返しに よる熱疲労等に耐えることが要求され，そのためには作製
された傾斜機能材料に対してこれらの耐熱特性を十分に評 価しなければならない。それと同時に，冷却材の使用量を 最小限に括さえ宇宙往還機のペイロードを確保する上で重 要な遮熱性能 ${ }^{(6)}$ を正確に評価する必要がある.

特性評価法として, 実際に使用される環境下での性能評 価試験法が種々提案されてきている(7)(8). しかし，迅速な FGM 開発を行らためには，大規模な実環境評価試験を実 施する以前に実験室レベルでのスクリーニング試験が不可 欠であり，小型サンプルを用いた基礎評価試験法の確立が 要望されている.

本研究では, 金属/セラミックス系耐熱傾斜機能部材で 想定される熱負荷を模擬するためにガスバーナー局部加熱 試験法を考案した. 本方法は, $\mathrm{H}_{2} / \mathrm{O}_{2}$ 混合ガスを用いて, 宇宙往還機推進システムの燃焼器内壁の環境(9)を模擬し, また，比較的安価に傾斜機能材料の熱機械的特性評価のた めの模擬試験環境を提供するものである. 本報告では, ジ ルコニア/ステンレス鋼系焼結傾斜機能材料を対象に定常 加熱試験を実施し，遮熱性・耐熱性を評価するとともに， バーナー加熱環境下に打ける破壊発生条件について検討し た結果について述べる.

* 東北大学工学部材料加工学科(Department of Materials Processing, Faculty of Engineering, Tohoku University, Sendai) 


\section{II. 実 験 方 法}

\section{1. バーナ一加熱試験装置}

試作したバーナー加熱試験装置は, Fig. 1 亿示すよう 飞, 火口が数 $\mathrm{mm}$ の市販のガスバーナートーチを使用し た簡便な装置である．宇宙往還機などの推進システムの環 境を模擬するために燃料ガスとして水素ガス，酸化材とし て酸素ガスを用いた．種々の燃焼環境および熱出力を得る ために，それぞれのガスの流量および混合比をマスフロー コントローラーを用いて正確に制御した。 また，冷却水流 量計によって冷却水の流量を制御し, 試料裏面の冷却条件 を一定に保持した.

Fig. 1 亿示したように，傾斜機能材料は銅製のホルダー (Fig. 1 詳細図)に銀口一付けし，さらに，水冷チャンバー 上部内縁周に沿ってはんだ付けして固定した。したがっ て，試料の変形は銅製ホルダーによって拘束されている. 側面は断熱材で保護し，火炎が直接側面にあたるのを防ぐ ため，試料の上面と高さが一致するように遮熱板を設置し た. 熱的境界条件は，表面加熱および裏面冷却で側面は断 熱である.

試料の表面温度 $\left(T_{\mathrm{s}}\right)$ は, 燃焼ガスによる赤外線吸収バ ンドをフィルタリングした放射温度計により測定した．試 料の放射率 $(\varepsilon)$ は，傾斜機能材料を作製する場合と同じ条 件で焼結したジルュニア単相材を，均熱师内で加熱して校 正して得た数值である $\varepsilon=0.74$ を用いた。一方，Fig. 1 に 示すよらに試料裏面近傍和よび銅ホルダー内に, 直径 1 $\mathrm{mm}$ の細孔を，側面から中心に向ってホルダー上面から $3 \mathrm{~mm}$ 間隔で加工し, 直径 $0.5 \mathrm{~mm}$ の $\mathrm{CA}$ シース熱電対を 装填した。これらの熱電対叔よび放射温度計の出力值を

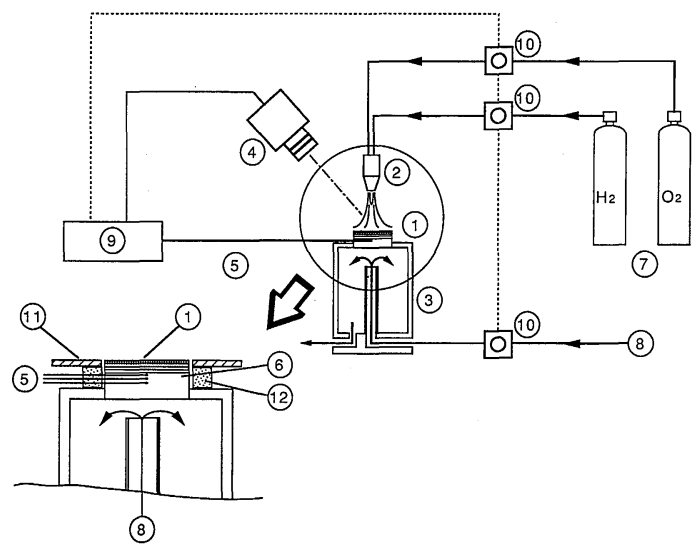

Fig. 1 Test system and sample setting configuration for burner heating test of functionally gradient materials (FGM). (1) FGM sample, (2) torch burner, (3) water cooled chamber, (4) emission pyrometer, (5) thermocouple, (6) Cu sample holder, (7) fuel gases, (8) cooling water, (9) control unit, (10) regulate valve, (11) heat shield, (12) insulator.
$\mathrm{A} / \mathrm{D}$ 変換器を通して，パーソナルコンピュータに転送し， 平均の熱流速 $(Q)$ 扤よび試料の裏面温度 $\left(T_{\mathrm{b}}\right)$ を算出した. また, 表面温度と裏面温度の差から温度落差 $\Delta T$ を求め た.

\section{2. 焼結傾斜機能材料試験片の調製}

原料粉末として, 平均粒径 $0.07 \mu \mathrm{m}$ の $\mathrm{ZrO}_{2}-3$ $\mathrm{mol} \% \mathrm{Y}_{2} \mathrm{O}_{3}$ (3Y-PSZ) 粉末と平均粒径 $3 \mu \mathrm{m}$ のステンレス 鋼粉末を用いた．これらの原料粉末を所定の割合でボール ミルにより湿式混合した. 予め設定した傾斜組成分布に従 って段階的に原料粉を充填し，内径 $30 \mathrm{~mm}$ の金型を用い て $100 \mathrm{MPa}$ で予備形成した後, $200 \mathrm{MPa}$ の静水圧下で本 成形した.

上記成形体を，内面を $\mathrm{BN}$ 粉でューティングした内径 $30 \mathrm{~mm}$ のアルミナ製ダイスに装填し, $\mathrm{Ar}-5 \% \mathrm{H}_{2}$ 雾囲気中 で $1473 \mathrm{~K}, 1 \mathrm{~h}, 30 \mathrm{MPa}$ の条件でホットプレスした. 作 製した試料の寸法，形状をFig. 2 亿，また組成分布を Fig. 3 亿示す. 断面組織写真の一例を Fig. 4 亿示すが, き裂などの欠陥はなく健全な焼結傾斜機能材料が作製され た.

各試料は，均熱炉内で $973 \mathrm{~K}, 10 \mathrm{~min}$ の条件で銅製ホル ダーに銀ロー付けした後(Fig. 5 に外観を示す)，バーナ 一加熱試験に供した.

\section{3. バーナ一加熱試験方法}

バーナー加熱試験は，混合ガス流量 $6 \sim 30 \mathrm{~L} / \mathrm{min}$ ，冷 却水流量 $5 \mathrm{~L} / \mathrm{min}$ で実施した。混合比は $\mathrm{H}_{2} / \mathrm{O}_{2}=2 / 1$ を 標準に，幾分水素過剩側に設定した ${ }^{(9)}$. Fig. 6 亿本試験 に打ける加熱/冷却プログラムを示す。試料表面温度拈よ び内部温度が汇ぼ定常状態になった後, $2 \mathrm{~min}$ 保持し, 一 度室温まで冷却する.試料表面を光学顕微鏡によって観察 し，き裂怙よび脱落破壊の有無を確認し，損傷がない場合 はさらにバーナ出力を昇温する，そして，損傷が確認され るまでバーナー出力を上昇させながら加熱冷却を繰返し， 表面き裂が観察された時点で加熱試験を終了する．各段階

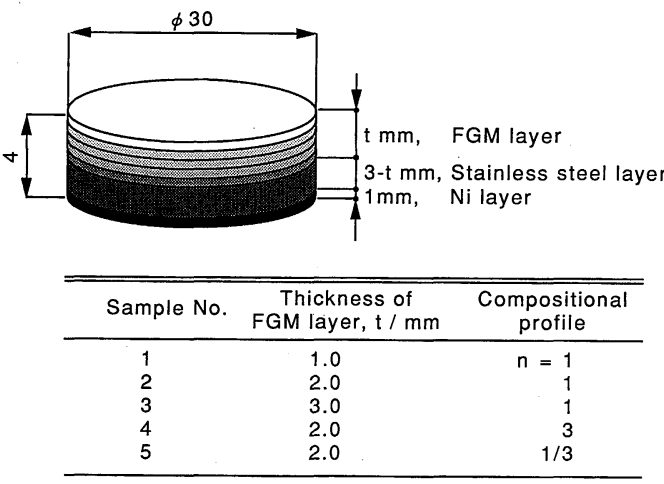

Fig. 2 Thickness and compositional profile(3) of sintered functionally gradient materials. 

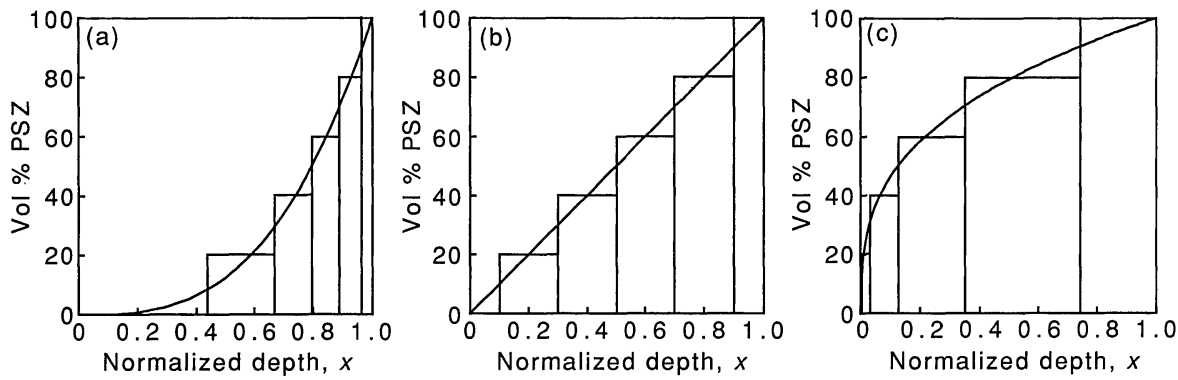

Fig. 3 Compositional profiles ${ }^{(3)}$ of the functionally gradient materials employed in the present investigation. (a) concave profile $(n=3)$, (b) linear profile $(n=1)$, (c) convex profile $(n=1 / 3)$.

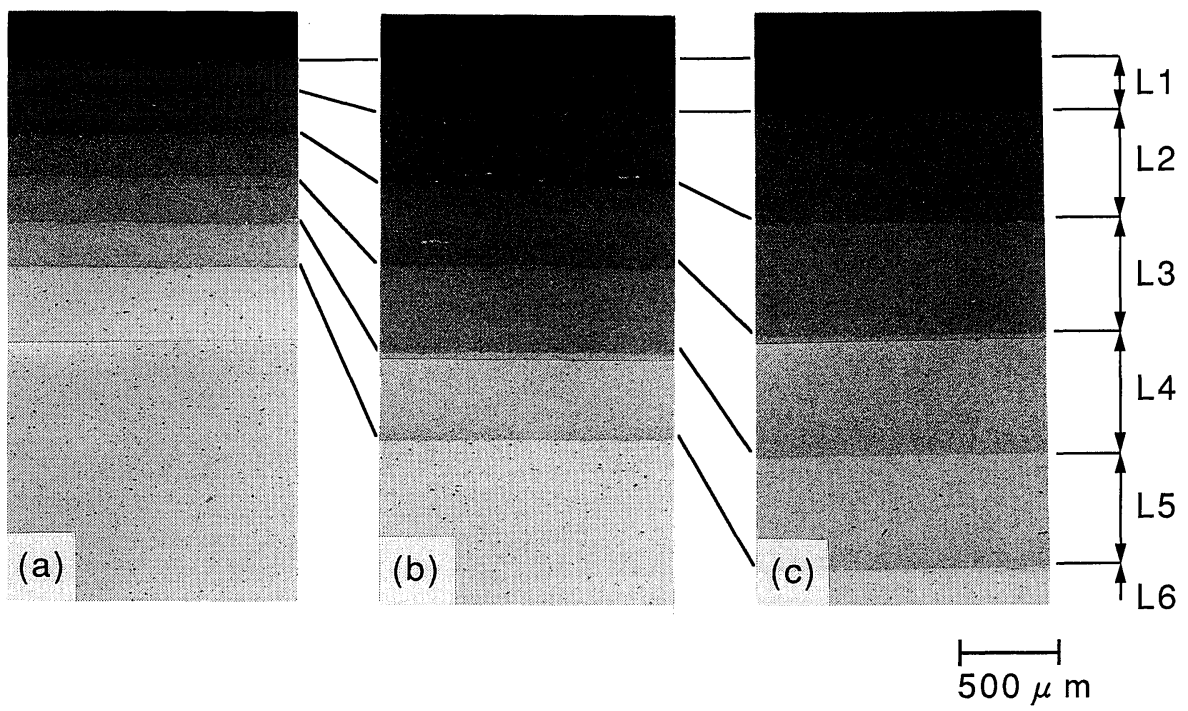

Fig. 4 Cross sections of the three typical PSZ/stainless steel functionally gradient materials (FGM). (a) $1 \mathrm{~mm}$, linear profile $(n=1)$, (b) $2 \mathrm{~mm}$, linear profile $(n=1)$, (c) $3 \mathrm{~mm}$, linear profile $(n=1)$. L1: PSZ, L2: $80 \%$ PSZ, L3: 60\%PSZ, L4: 40\%PSZ, L5: 20\%PSZ, L6: stainless steel.

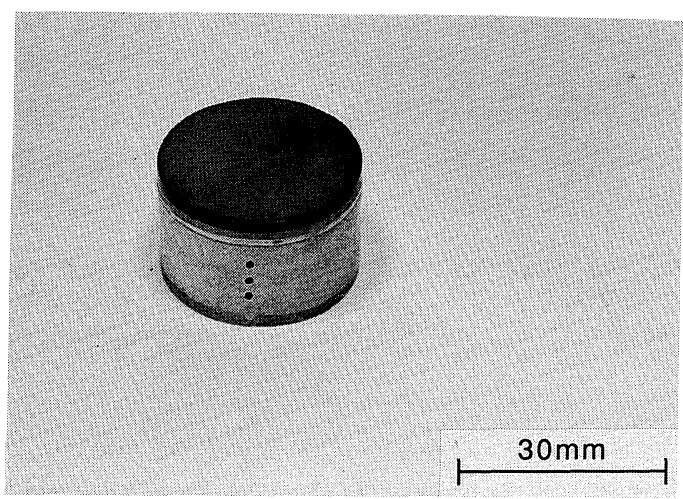

Fig. 5 Appearance of PSZ/stainless steel functionally gradient material (FGM), as blazed on a copper sample holder for burner heating test.
での試料表面温度, 裏面温度, 温度落差および平均の熱流 速を計測あるいは算出した，試験後，試料を切断・研磨 後, 断面を光学顕微鏡および SEM を用いて観察し, 割れ の発生特よびその形態を観察した.

\section{4. 遮熱性の評価法}

一般に，遮熱性を表す方法としては有効熱伝導率 $\left(\lambda_{\text {eft }}\right)$ で表す場合が多い。しかし，傾斜機能材料では，有効熱伝 導率が同一でも厚さや組成分布が異なると通過する熱流速 が変化する．すなわち FGM 層内の組成分布と厚さの組合 せによって，有効熱伝導率が等しい傾斜機能材料を無数に 作製することが可能であるが，温度落差に対する通過熱流 速はそれぞれ異なった值を取る．たとえば，Fig. 2 で示し た試料 $1,2,3$ の有効熱伝導率はほぼ等しいが熱流束 $(Q)$ と温度落差 $(\Delta T)$ との関係は後で述べるように異なったも のになる。したがって，単に有効熱伝導率を用いて，個々 の FGM 材の遮熱性を表すのは適切ではない. 


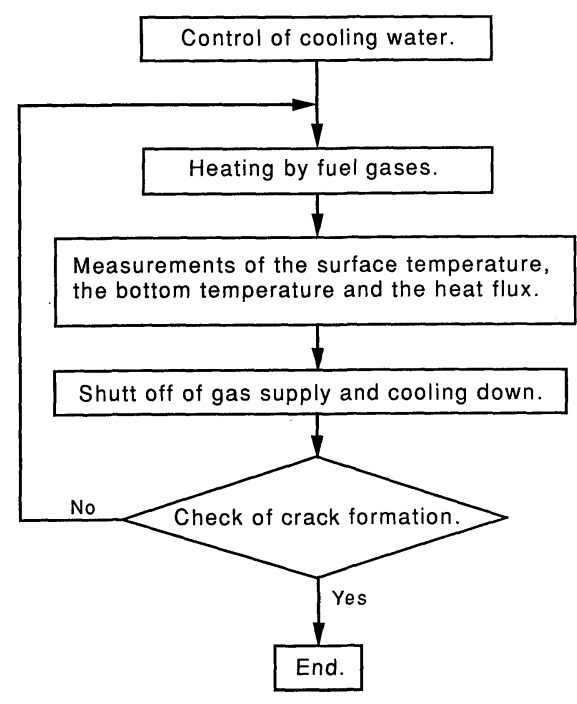

(a)

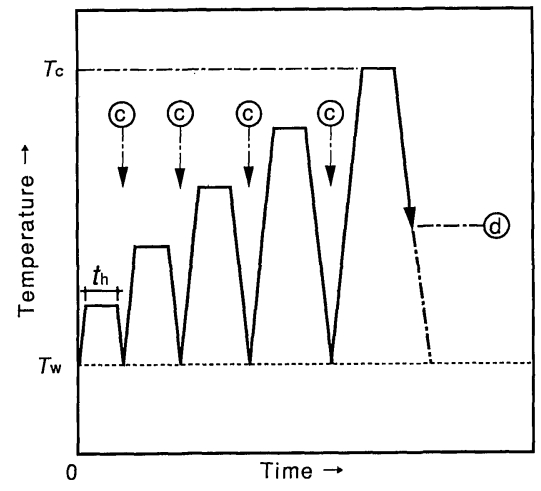

(b)

Fig. 6 Burner heating test scheme. (a) Test procedure, (b) Heating and cooling program. ( $T_{\mathrm{c}}$ : Critical temperature, $T_{\mathrm{w}}$ : The temperature of cooling water: $t_{\mathrm{h}}$ : Holding time $120 \mathrm{~s}$, c: Check of crack formation, d: Surface crack formation.)

一方，傾斜機能材料を通過する熱流速は次式で表される.

$$
Q=K \cdot\left(T_{\mathrm{s}}-T_{\mathrm{b}}\right)
$$

$$
1 / K=d_{1} / \lambda_{1}+d_{2} / \lambda_{2}+d_{1} / \lambda_{2}+\cdots+d_{\mathrm{n}} / \lambda_{\mathrm{n}}
$$

ただし， $Q$ : 熱流速, $K$ : 熱通過率, $T_{\mathrm{s}}$ : 表面温度, $T_{\mathrm{b}}$ : 裏面温度, $d_{\mathrm{n}}: \mathrm{n}$ 層の厚さ, $\lambda_{\mathrm{n}}: \mathrm{n}$ 層の熱厷導率である.

$1 / K$ はいわゆる熱抵抗であり， $1 / K$ が大きくなると温 度落差に対する熱流速が小さくなり, 遮熱性が向上したこ とがわかる，そこで，本研究では $1 / K$ を用いて各々の傾 斜機能材の遮熱性を評価した.

\section{5. 熱応力解析}

バーナー加熱試験時に発生する熱応力状態を把握するた めに有限要素法 (FEM) による定常熱応力解析を実施した. 計算には汎用有限要素解析法である NASTRANを用い た. 直径 $30 \mathrm{~mm}$ の焼結傾斜機能材料を銅製ホルダーに銀 ロ一付した状態すなわち裏面を拘束した状態の軸対称問題 として取扱った ${ }^{(5)}$. Fig. 7 亿解析に用いたモデル困を示 す. 熱的環境条件として, 表面には放射温度計で測定した 温度分布，裹面には冷却水の温度を与光，側面は断熱と乙 た. 熱伝導率, 熱膨張係数などの熱的性質およびヤング 率，ポアソン比などの機械的性質は実測值 ${ }^{(10)}$ をいた。

\section{III. 実験結果および考察}

\section{1. 傾斜材表面の温度分布および限界表面温度}

定常加熱状態になるのは，ガスバーナー加熱を開始して から約 $20 \mathrm{~s}$ である. Fig. 8 は，定常加熱状態に招いて放 射温度計で測定した試料表面の温度分布を示している. 温

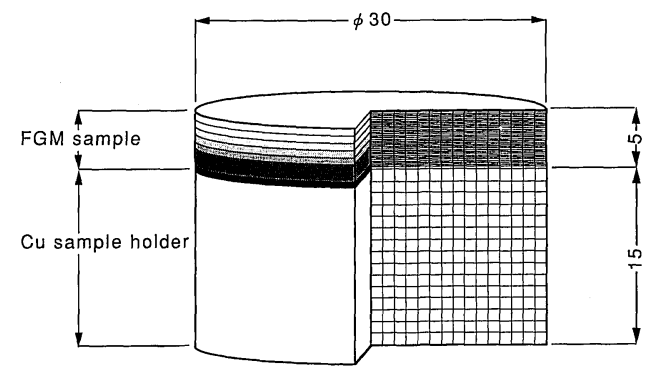

Fig. 7 Mesh division of a disk-shaped functionally gradient material for finite element analysis. Elements: 1125 , Nodal points: 1216 . (dimension in $\mathrm{mm}$.)

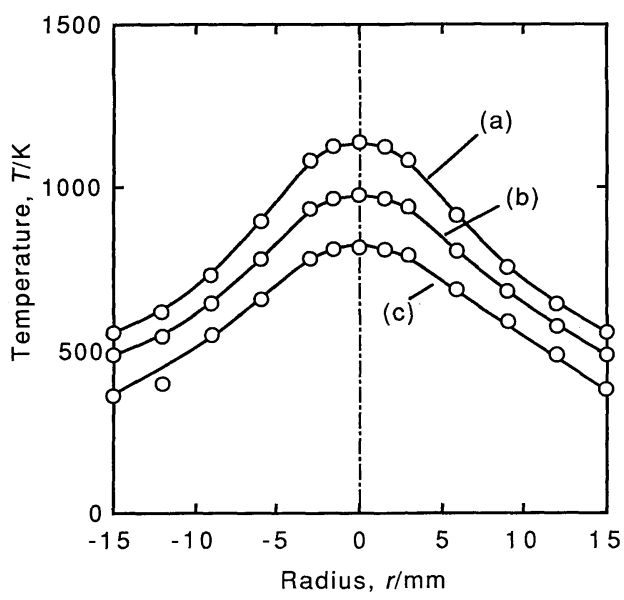

Fig. 8 Surface temperature distributions at the sample surface during burner heating test. (a) $\mathrm{H}_{2}: 9.0 \mathrm{~L} /$ min., $\mathrm{O}_{2}: 3.6 \mathrm{~L} / \mathrm{min}$., (b) $\mathrm{H}_{2}: 7.0 \mathrm{~L} / \mathrm{min}$., $\mathrm{O}_{2}: 2.8 \mathrm{~L} /$ min., (c) $\mathrm{H}_{2}: 5.0 \mathrm{~L} / \mathrm{min}$., $\mathrm{O}_{2}: 2.0 \mathrm{~L} / \mathrm{min}$. 


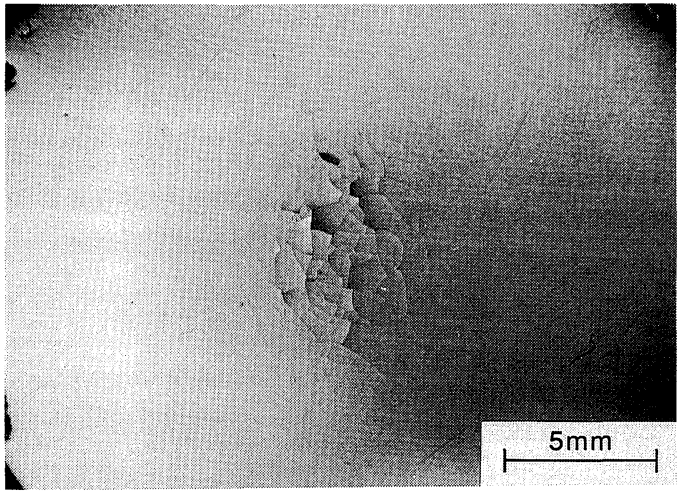

Fig. 9 Macro view of the typical damage at the PSZ surface after burner heating test.

度分布は，中心部が高く，端部で低い山形の分布をしてい るが，中心から $3 \mathrm{~mm}$ 程度までは比較的なだらかに減少 していることがわかる.これは，ガスバーナーの火炎の外 径が約 $10 \mathrm{~mm}$ であり, 試料の外径(約 $30 \mathrm{~mm}$ )に比べて小 さいためである. バーナーの出力 (以後, 混合ガス流量で 表す。）を上昇させると，温度は全体的に上がるが，温度 分布の形状は火口と試料表面との間の距離を一定にすると 変化しないことがわかった．本研究では中心部の温度を試 料表面の代表温度としている.

Fig. 9 は，バーナー加熱試験後の試料表面の代表的な 光学顕微鏡写真である. ある温度以上に表面が加熱される と, き裂が発生するようになり，さらにバーナーの出力を 増すにつれてき裂の領域が拡大し，さらに一部が脱落する よらになる、き裂はバーナーの炎があたる中心部から発生 し，亀甲状に発達していることがわかる．限界表面温度 は, このような損傷が確認された時点での最高表面温度で

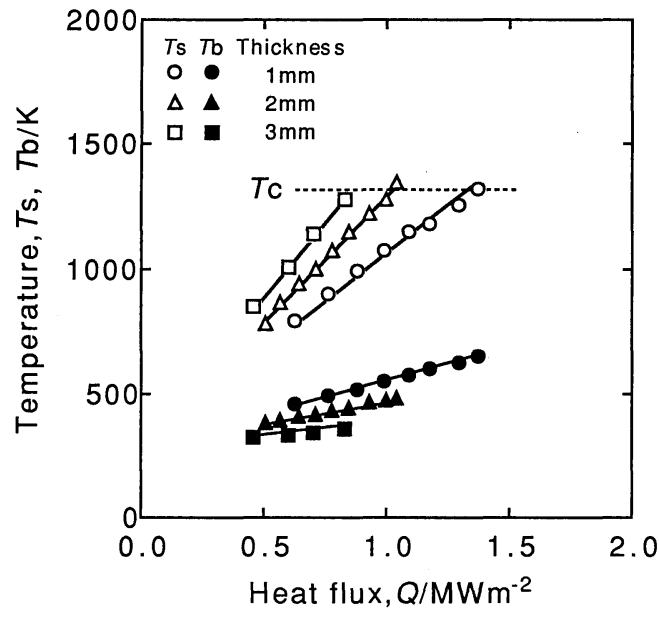

Fig. 10 Sample surface and bottom temperature $\left(T_{\mathrm{s}}\right.$ and $T_{\mathrm{b}}$ ) vs. heat flux for PSZ/stainless steel FGM. ( $T_{\mathrm{c}}$ is the critical temperatures of surface crack formation.)
ある。

\section{2. 焼結傾斜機能材料の遮熱性および耐熱性の評価 \\ （1）遮熱性の評価}

Fig. 10 は，ガスバーナーの出力を逐次上昇させた時の 表面温度扣よび裏面温度の変化を平均熱流束に対して示し たものである．試料の組成は直線分布で傾斜組成制御層の 厚さはそれぞれ 1,2 拉よび $3 \mathrm{~mm}$ である. 冷却水により 強制冷却しているので裏面温度の上昇は小さいが，同一の 熱流速に対して，厚さが大きいほど表面温度は高くなる。 すなわち, 温度落差 $(\Delta T)$ が大きくなるので, 遮熱効果は 増大する．また，表面温度のいずれの場合も直線的に増加 している.これは, ジルコニア拉よびステンレス鋼の場 合, 熱伝導率の温度依存性は比較的小さいことが知られて 扣り，したがって，FGM 層全体としての有効熱伝導率の 温度依存性も小さいため, 直線的に変化したものと考えら れる。

Fig. 11 は，FGM 層の厚さが $4 \mathrm{~mm}$ で種々の組成分布 に対して，平均の熱流速と温度落差の関係を示したもので ある. Fig. 11 に示された直線の傾きが，熱抵抗 $(1 / K)$ を 表して拈り傾きが大きい方が遮熱効果が高いことを示して いる. $n$ は組成分布を表すパラメータ(3)であり $(n>1$ 凹分 布， $n=1$ 直線， $n<1$ 凸分布）凸分布の方が遮熱性が高い ことがわかる. $n$ が同じ場合，厚さが 2 倍になると $1 / K$ も 2 倍になり遮熱性が向上することになる.

以上のように，1/Kを用いると，組成分布と厚さを含 めて傾斜機能材料の遮熱性を評価することができる．本材 料系の場合，組成分布や傾斜組成制御層の厚さを変化させ ることで広い範囲にわたって，遮熱性を制御できることが わかった。

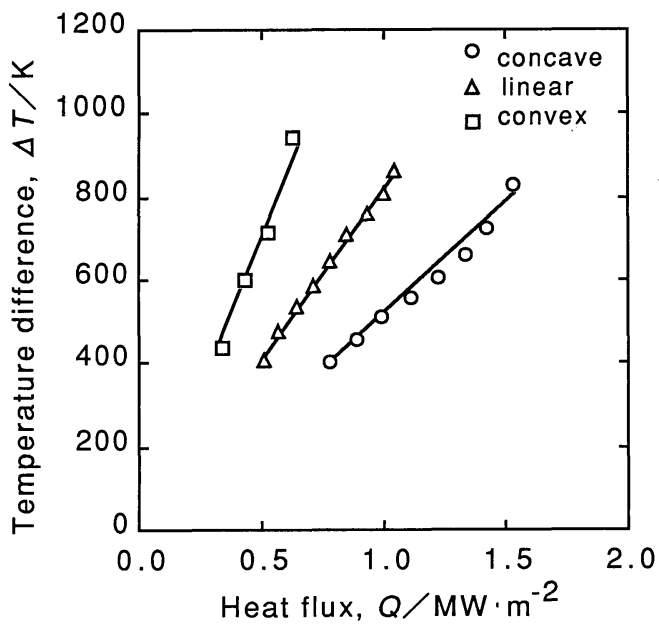

Fig. 11 Temperature difference between the heated sample surface and cooled bottom vs. heat flux for PSZ/stainless steel FGM. 


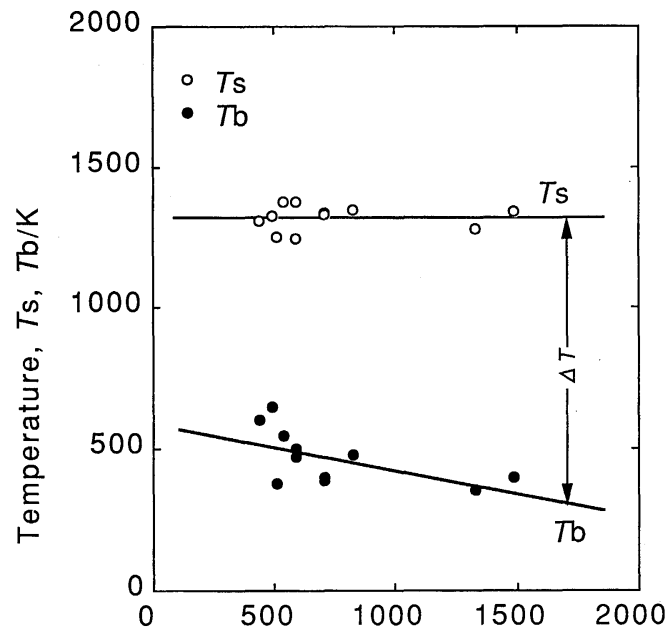

Thermal resistance, $R / \mathrm{K} \cdot \mathrm{MW}^{-1} \cdot \mathrm{m}^{2}$

Fig. 12 Critical temperature for the crack formation vs. thermal resistances of the PSZ/stainless steel FGM.

\section{（2）耐熱性の評価}

Fig. 12 に熱抵抗 $(1 / K)$ とさ裂の発生が観察された限界 表面温度の関係を示す. 裏面温度も同時に示してあり, 遮 熱性が高いほど温度落差は増大している.しかし，き裂の 発生が観察された表面温度の限界温度は約 $1300 \mathrm{~K}$ 付近の 狭い温度範囲にあり，ほぼ一定になることがわかった。

Fig. 12 に明確にみられるように, 試料の直径, 厚さおよ び組成分布が異なっていても，限界表面温度はそれらの影 響をあまり受けない，若干バラッキが見られるのは実験方 法で述べたように，段階的に上昇させる熱負荷の加熱ステ ップが比較的粗であったこと，また，表面温度の測定誤差 のためと考えられる.

ジルコニアセラミックスは $1500 \mathrm{~K}$ を越える高温でも熱 的には安定であり，均一加熱した場合には破壊することは ないしかし，本測定条件である温度落差下に拈いては， Fig. 12 に示すように，比較的せまい温度範囲内にその限 界温度が存在することがわかった。 この限界温度領域が本 傾斜機能材料としての耐熱性を表していると考えられる.

以上のことは，大きな熱負荷に対して本材料系を用いる 場合には，多少遮熱性を低下させても通過熱流束をかせぐ ことで表面温度の上昇を限界温度以下に和さえる必要があ ることを示している.

\section{3. 限界温度での表面割れの発生およびその形態}

ガスバーナーの火炎があたる中心部から亀甲状に発達し た割れはすでに Fig. 9 に示した。き裂の発生した試片の 表面中央部の拡大写真和よび断面写真を Fig. 13, 14, 15 に示す. Fig. 14, 15 の断面観察の結果から，割れは試料 表面から垂直に進展した縦さ裂であることがわかるフプラ

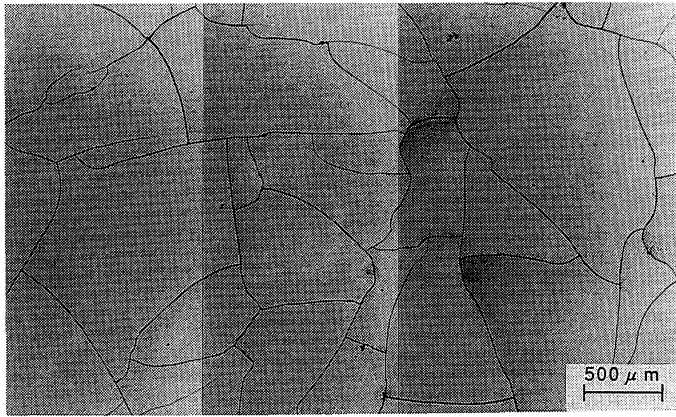

Fig. 13 Enlarged view of the surface cracks formed by heating above the critical temperature in burner heating test (PSZ/stainless steel FGM).

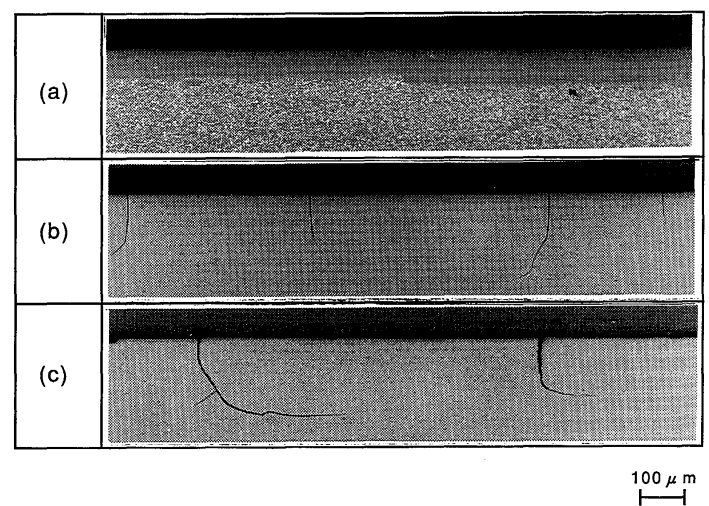

Fig. 14 Cross sections of PSZ/stainless steel FGM after burner heating test. FGM thickness variation: (a) $1 \mathrm{~mm}$, linear profile $(n=1)$ (b) $2 \mathrm{~mm}$, linear profile $(n=1)$ (c) $3 \mathrm{~mm}$, linear profile $(n=1)$. (The cracks initiated vertically at the ceramic surface.)

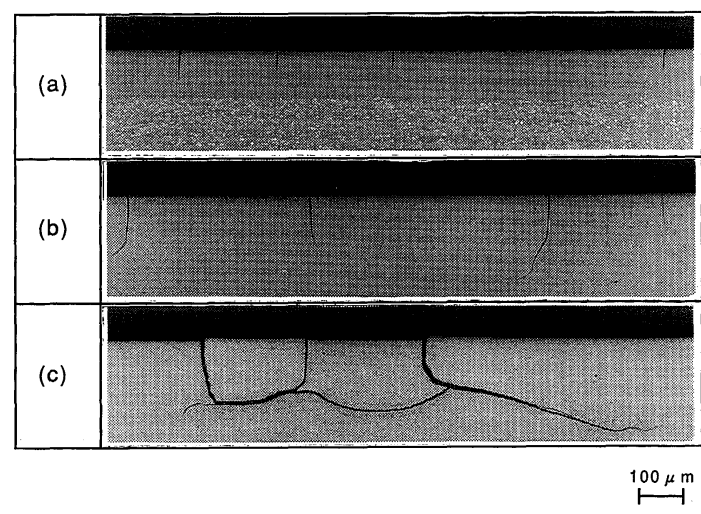

Fig. 15 Cross sections of PSZ/stainless steel FGM after burner heating test. FGM compositional profile variation: (a) $2 \mathrm{~mm}$, concave profile $(n=3)$ (b) 2 $\mathrm{mm}$, linear profile $(n=1)(\mathrm{c}) 2 \mathrm{~mm}$, convex profile $(n=1 / 3)$.

ズマコーティング材では母材との接合界面にはく離が発生 することがあるが(11)(12), 本研究では段階的に制御した各 
組成の境界に層状のはく離き裂は観察されなかった。ま た，加熱中の試料表面を目視で観察している限り，割れの 発生は確認できず, いずれの場合も，冷却時にき裂が発生 していることがわかった、レーザー局所加熱試験では $\mathrm{AE}($ アコースティックエミッション)を併用することによ ってき裂発生時間をモニタリングし，き裂の発生はレーザ 一照射後の空冷時であることが示されている(13).

Fig. 14 拈よび Fig. 15 は FGM 層の厚さ，組成分布形 状の異なる試料の断面写真であり，き裂の進展の様子を示 している.Fig. 14 は組成分布形状は同じであり，FGM 層の厚さが異なる場合である.FGM 層の厚さが厚くなる につれ発生した綎割れの深さが深くなっている，また，表 面からの深さが 100～120 $\mu \mathrm{m}$ 程度の深さまでは表面から 垂直に進展している. 一方, 表面からの深さが約 $150 \mu \mathrm{m}$ 付近から，き裂が表面に対して平行に曲がる，いわゆるき 裂の偏向が観察された。一方, Fig. 15 は, 組成傾斜層の 厚さは一定で，組成分布が異なる場合である．表面のセラ ミックス層の厚さが厚いものほど進展したさ裂の長さが大 きく, 表面からの深さが約 $150 \mu \mathrm{m}$ 以上になるとき裂の偏 向が生じることがわかった.

偏向したさ裂がさらに進展すると隣り合うき裂の合体が 扣こり，これによって脱落破壊に至るものと考兄られる.

\section{4. バーナ一加熱試験における割れ発生機構}

表面割れの発生およびき裂進展挙動は，加熱および冷却 中の内部熱応力状態と密接に関係していると考兄られる. ここでは有限要素法による熱応力解析結果を参考にしてき 裂発生機構について考察する。

Fig. 16 に，バーナー出力が限界出力の条件で定常加熱 したときの試料表面に和ける，半径方向拈よび周方向の応 力 $\sigma_{\mathrm{r}}, \sigma_{\theta}$ の分布を示す. 中心部では， $\sigma_{\mathrm{r}}, \sigma_{\theta}$ の両応力とも に $1 \mathrm{GPa}$ を越えるほぼ等しい值の圧縮応力となってい る(14)(15)。一方，側面付近では両者に若干の差はあるが， それらの值はともに小さい。

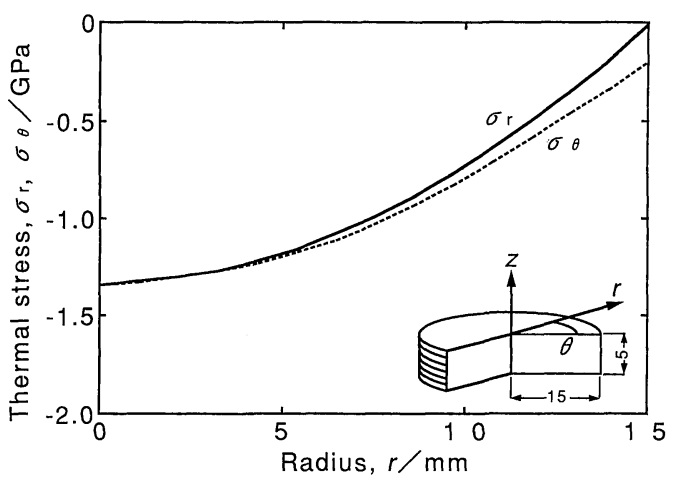

Fig. 16 The distributions of the thermal stresses $\sigma_{\mathrm{r}}$ and $\sigma_{\theta}$, at the heating surface of a disk shaped FGM with linear composition control (PSZ/stainless steel FGM).

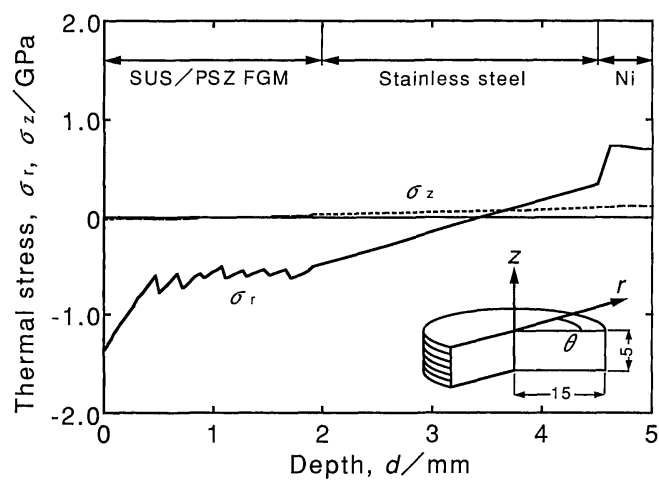

Fig. 17 The distributions of the thermal stresses, $\sigma_{\mathrm{r}}$ and $\sigma_{z}$ along the center axis of a disk-shaped FGM sample from surface to bottom (PSZ/stainless steel FGM).

Fig. 17 は中心軸上の $\sigma_{\mathrm{r}}$ の分布および $\sigma_{\mathrm{z}}$ の分布(厚さ 方向の応力)を示したものである. 表面で圧縮応力は最大 となり，内部になるにつれ減少し，ステンレス鋼の延長層 内で $\sigma_{\mathrm{r}}=0$ となり, $\mathrm{Cu}$ ブロックへの銀ロー付けのために 形成した $\mathrm{Ni}$ 層内では引張応力が生じている. 一方, 中心 軸上の $\sigma_{z}$ の値は全領域にわたって小さい， $\sigma_{z}$ は剥離応力 に対応するものであるが，その值は小さく，剥離を生じさ せるためには不十分である.したがって，バーナー加熱さ れた傾斜機能材料は，主として表面層に 2 軸の大きい圧 縮応力が作用しているとみなしてよい.

しかし，Fig. 9 に示したよらに観察されたき裂は，表面 から垂直に進展した縦割れであり，圧縮応力下で生じたと は考えにくい.

そこで均一材ではあるが INCONEL alloy 617 表面を高 温加熱, 裏面を液体窒素で冷却する条件で熱弾塑性解析し た報告(16)の一例を Fig. 18 に示した．表面中央の $\sigma_{\mathrm{r}}$ につ いて加熱開始から冷却過程までの変化を示している. 加熱 初期に高い圧縮応力が生じて拉り，これは先に示した弾性 解析の結果と一致している. 表面温度が定常状態になると 応力が緩和してくるのは, 高温に捈いて塑性変形が起こっ たためであると考えられる。一方，冷却過程になると，一 転して引張応力が生じている．その値は，約 $1 \mathrm{~s}$ 後に最大 となり，その後減少している．この計算結果を踏をえて， 本傾斜機能材料のバーナー試験に扣ける縦き裂発生を考察 すると，加熱時にジルコニアが塑性変形し，冷却時にその 破壊応力を越える高い引張応力が表面で生じたとすれば, 表面から縦割れが発生するものと考えられよう.

室温では脆性のセラミックスもある程度の高温になると 非弾性的に変形すること(17)(18) 打よびその破壊機構が脆性 から延性に遷移すること(19)-(22) が酸化物系括よび非酸化 物系七ラミックスに対して研究されている. その機構は鉄 鋼材料が呈する脆性-延性遷移と類似な挙動として考えら れている(19). 


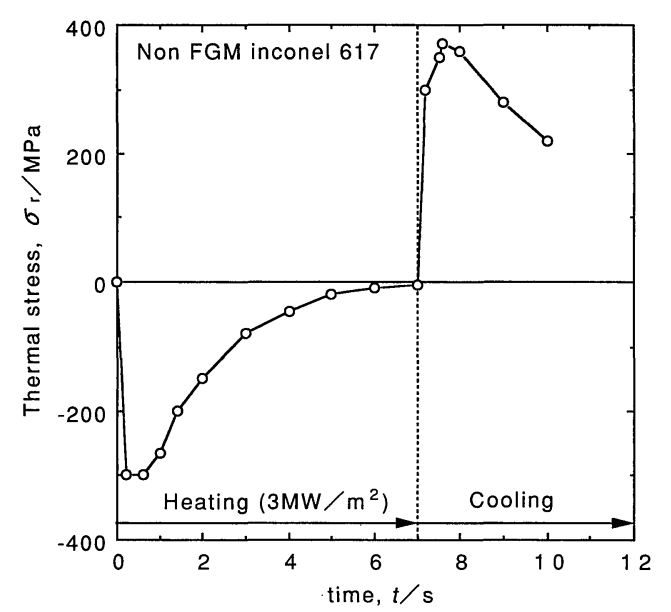

Fig. 18 Variation of thermal stress $\sigma_{\mathrm{r}}$ at the center of the surface during heating and cooling cycle. (The calculation was made by FEM considering the nonlinearity and temperature dependence of material properties of Inconel 617.)

本研究で用いたイットリア部分安定化ジルコニア焼結体 (PSZ) は超塑性現象を示すセラミックスであり (23)-(26)，平 均粒径 $0.3 \mu \mathrm{m}$ の等軸形状 3Y-PSZ 焼結体の圧縮試験では, $1623 \sim 1773 \mathrm{~K}$ ，ひずみ速度 $\left(10^{-3} \sim 10^{-5} \mathrm{~s}^{-1}\right)$ の条件のも とで超塑性変形を生じることが報告されている. 一般にひ ずみ速度と応力の関係は

$$
\dot{\varepsilon}=B \sigma^{n}=/ d^{p} \exp (-\Delta Q / R T)
$$

で表され，現象論的には次式が得られている(25).

$$
\dot{\varepsilon}=2 \times 10^{5} \exp (-380000 / R T) \sigma^{2.1} / d^{1.8}
$$

そこで変形機構が同一で変化しないと仮定してバーナー試 験の定常加熱中の 2 軸圧縮応力下でのひずみ量を推定し てみた、な拉, 式 (4)の係数は温度, ひずみ速度, 微視 組織に敏感なので上記仮定はあくまでも第一近似である.

Fig. 16 に示した条件は, 表面温度 $1300 \mathrm{~K}$ 最大圧縮応力 $1.3 \mathrm{GPa}$ である. 式( 2 )に代入してひずみ速度を求め, 保 持時間 $2 \mathrm{~min}$ の条件でひずみ量を計算すると，0.044とな

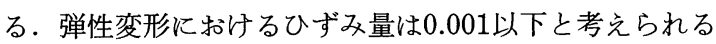
から，上記ひずみ量はそれを大きく越えている．ひずみ速 度が大きく, 温度が低くなるにつれて変形抵抗が大きくな り均一な変形は生じにくくなるが, 表面温度 $1300 \mathrm{~K}$ 最大 圧縮応力 $1.3 \mathrm{GPa}$ の条件では粒界すべりを含む局所的な 塑性変形が生じることは十分に予想される.

以上の考察をまとめると, 本研究で実施したバーナー加 熱試験に扣いて発生する縦割れの発生メカニズムは,

Fig. 19 に模式的に示したが，以下の上うに考えられる. バーナー加熱時には FGM 表面部は高い 2 軸圧縮応力状態 となる．表面温度が，非弾性変形が顕著になる温度より低 い場合は, 冷却過程で可逆的に変形がもとの状態にもど る、遷移温度を越えて加熱されても，塑性変形量が微小な 場合は，ほぼ初期応力状態にもどる。しかし，遷移温度以

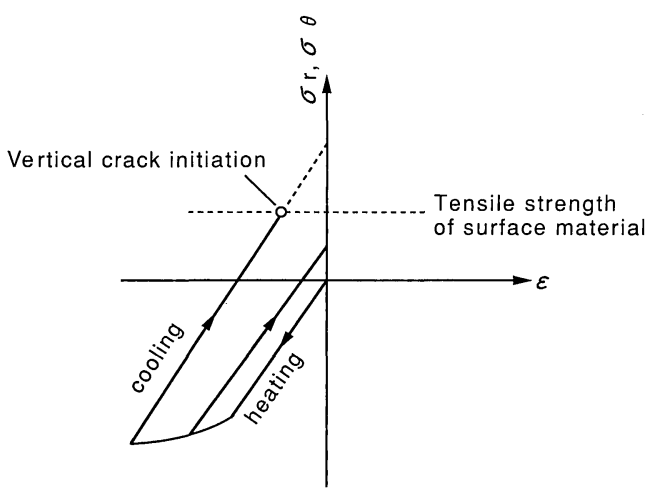

Fig. 19 Conceptual stress-strain model for vertical crack formation in burner heating test $\sigma_{\mathrm{r}}, \sigma_{\theta}$ are radial and circumferential stress, respective, $\varepsilon$ is strain.

上に加熱され，しかも十分に高い圧縮応力が生じる場合 は, 著しい圧縮塑性変形が生じ, 冷却過程において応力が 引張応力となり, 破壊応力を越えれば縦割れが発生するこ とになる. Fig. 16 で示したよらに表面温度が $1300 \mathrm{~K}$ を 越えるよらな加熱条件では十分に高い 2 軸圧縮応力状態 になる.したがって，これにより非弾性変形が生じ，冷却 時発生する引張応力により縦割れが生じたと考えられる.

限界温度は約 $1300 \mathrm{~K} て ゙ ，$ 本ジルコニア材の脆性/延性 遷移温度とほぼ一致して扣り，試料の直径や厚さなどの寸 法, 組成分布形状によらず限界温度がほぼ一定であるのも このような破壊機構のためと考えられる。

\section{N. 結 論}

金属/セラミックス耐熱傾斜機能部材 (FGM)で想定され る熱負荷を模擬するために，ガスバーナー局部加熱試験装 置を試作し, ジルコニア/ステンレス鋼系焼結傾斜機能材 料を対象に定常加熱試験を実施した。

（1）遮熱性は個々の傾斜機能材料に対して熱抵抗 $(1 / K)$ で表すのが妥当であり, 組成分布や FGM 層の厚さの効果 を評価することができる。

（2）試料表面に損傷が確認された時点での最高表面温度 を限界温度と定義し，耐熱性を評価した。ジルコニア/ス テンレス鋼系焼結傾斜機能材料の限界温度はいずれの試料 でも約 $1300 \mathrm{~K}$ で浪ぼ一定であることを示した。

（3）観察された割れの形態は，縦割れであった. 熱応力 解析の結果, 試料表面の加熱部はほぼ面内の 2 軸圧縮応 力状態にあると考えられ，加熱領域内で非弾性変形が生 じ，冷却時に発生する引張応力により縦割れが生じると推 察された.

（4）試作したバーナー加熱試験装置は，比較的安価な試 験環境を提供するものであり，傾斜機能材料の耐熱性扣よ び遮熱性の基礎評価試験法として適している。 


\section{文献}

（1）新野正之, 平井敏雄, 渡辺龍三 : 日本複合材料学会 誌, 13(1987), 257.

（2）渡辺龍三: 機能材料, 4(1988), 51.

（3）川崎 亮, 渡辺龍三: 日本金属学会誌, 51(1987), 525.

(4) A. Kawasaki and R. Watanabe: Proc. 4th Intern. Symp. on Science and Technology of Sintering, Tokyo (1987), Elsevier, (1989), vol. 2, p. 1197-1202.

（5）川崎亮, 渡辺龍三: 粉体执よび粉末治金, 37 (1990), 253.

（6）冠 昭夫：昭和60年度宇宙輸送シンポジゥム, 宇宙 科学研究所, (1985), 75.

（7）能川彰長, 佐々木正樹, 前田修平, 足立直人 : 粉体 および粉末冶金, 37 (1990), 313.

（8）高橋秀明：粉体执よび粉末治金，37(1990), 913.

(9) 長島隆一: 内燃機関, 30 (1991), 46.

(10) 川崎 亮, 渡辺龍三 : 第 3 回傾斜機能材料シンポジ ウム講演集, 傾斜機能材料研究会, (1989), 35.

(11) A. G. Evans and J. W. Hutchinson: Int. J. Solids Structures, 20(1984), 455.

(12) R. L. Loh, C. Rossington and A. G. Evans: J. Am. Ceram. Soc., 69(1986), 139.
（13）橋田俊之, 高橋秀明, 宮脇和彦: 粉体执よび粉末治 金, $37(1990), 307$.

（14）宮脇和彦，橋田俊之，高橋秀明：粉体执よび粉末治 金, 37(190), 957.

(15) G. McDonald and R. C. Hendricks: Thin Solid Films, $\mathbf{7 3}(1980), 491$.

（16）原田 誠：FGM 分科会資料, 傾斜機能材料研究会, (1991).

(17) K. Niihara: Am. Ceram. Soc. Bull., 63(1983), 1160.

（18）前田康二：割業協会誌, 94(1986), 784 .

(19) G. H. Campbell, B. J. Dalglish and A. G. Evans: J. Am. Ceram. Soc., 72(1989), 1402.

(20) B. J. Dalglish, E. B. Slamorich and A. G. Evans: J. Am. Ceram. Soc., 68(1985), 575.

(21) M. L. Mecartney, W. L. Donlon and A. H. Heuer: J. Mater. Sci., 5(1980), 1063.

(22) E. J. Minford and R. E. Tressler: J. Am. Ceram. Soc., 66(1983), 338.

(23) A. G. Evans, J. R. Rice and J. P. Hirth: J. Am. Ceram. Soc., 58(1980), 368.

(24) P. C. Panda, R. Raj and P. E. D. Morgan: J. Am. Ceram. Soc., 68(1985), 522.

（25）若井史博, 阪口修司, 加藤英純：割業協会誌, $94(1986), 721$.

(26) Y. Yoshizawa and T. Sakuma: J. Am. Ceram. Soc., $73(1990), 3069$. 